\title{
Front Matter: Volume 7480
}

, "Front Matter: Volume 7480," Proc. SPIE 7480, Unmanned/Unattended Sensors and Sensor Networks VI, 748001 (30 October 2009); doi: 10.1117/12.848795

SPIE. Event: SPIE Security + Defence, 2009, Berlin, Germany 


\section{PROCEEDINGS OF SPIE}

\section{Unmanned/Unattended Sensors and Sensor Networks VI}

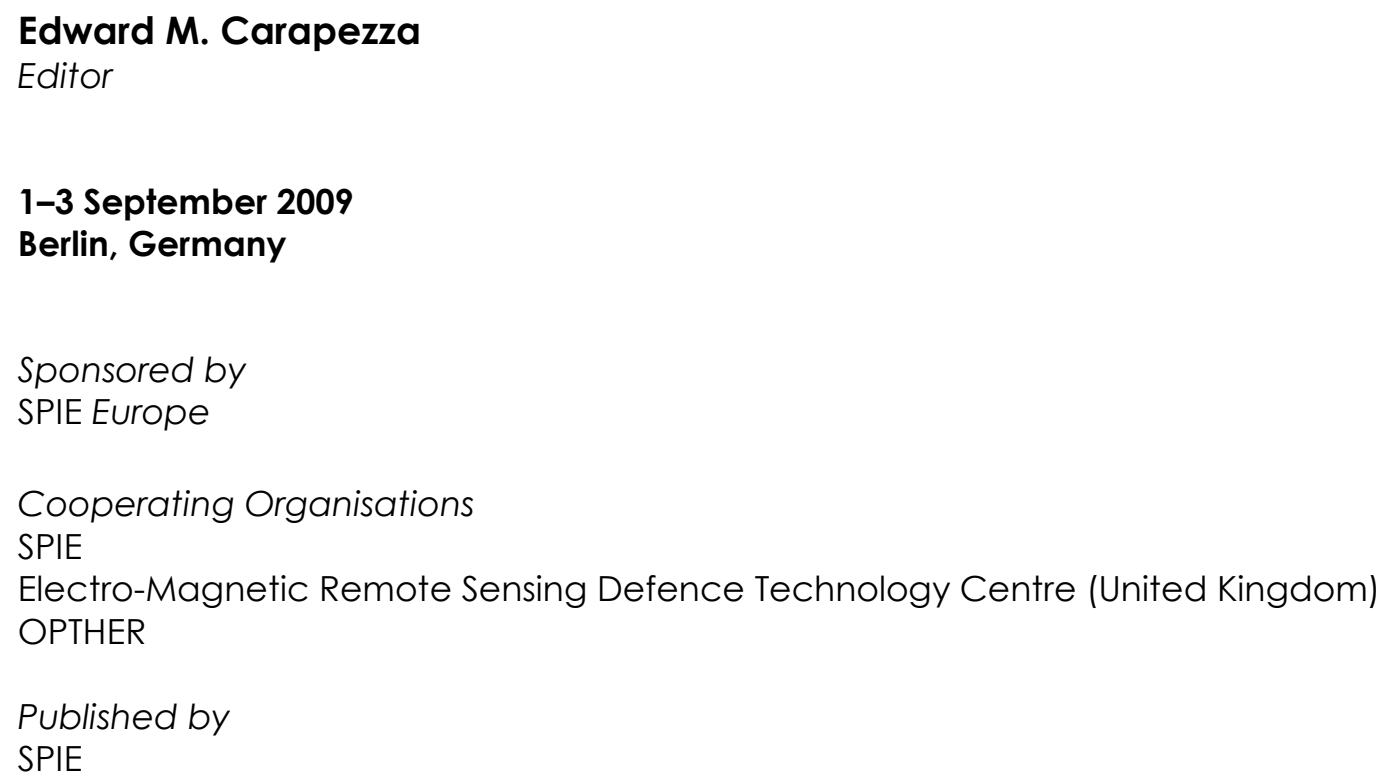


The papers included in this volume were part of the technical conference cited on the cover and title page. Papers were selected and subject to review by the editors and conference program committee. Some conference presentations may not be available for publication. The papers published in these proceedings reflect the work and thoughts of the authors and are published herein as submitted. The publisher is not responsible for the validity of the information or for any outcomes resulting from reliance thereon.

Please use the following format to cite material from this book:

Author(s), "Title of Paper," in Unmanned/Unattended Sensors and Sensor Networks VI, edited by Edward M. Carapezza, Proceedings of SPIE Vol. 7480 (SPIE, Bellingham, WA, 2009) Article CID Number.

ISSN 0277-786X

ISBN 9780819477866

Published by

SPIE

P.O. Box 10, Bellingham, Washington 98227-0010 USA

Telephone +1 3606763290 (Pacific Time) · Fax +1 3606471445

SPIE.org

Copyright (C) 2009, Society of Photo-Optical Instrumentation Engineers

Copying of material in this book for internal or personal use, or for the internal or personal use of specific clients, beyond the fair use provisions granted by the U.S. Copyright Law is authorized by SPIE subject to payment of copying fees. The Transactional Reporting Service base fee for this volume is $\$ 18.00$ per article (or portion thereof), which should be paid directly to the Copyright Clearance Center (CCC), 222 Rosewood Drive, Danvers, MA 01923. Payment may also be made electronically through CCC Online at copyright.com. Other copying for republication, resale, advertising or promotion, or any form of systematic or multiple reproduction of any material in this book is prohibited except with permission in writing from the publisher. The CCC fee code is 0277-786X/09/ $\$ 18.00$.

Printed in the United States of America.

Publication of record for individual papers is online in the SPIE Digital Library.

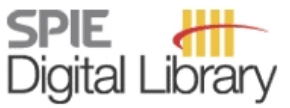

SPIEDigitalLibrary.org

Paper Numbering: Proceedings of SPIE follow an e-First publication model, with papers published first online and then in print and on CD-ROM. Papers are published as they are submitted and meet publication criteria. A unique, consistent, permanent citation identifier (CID) number is assigned to each article at the time of the first publication. Utilization of CIDs allows articles to be fully citable as soon they are published online, and connects the same identifier to all online, print, and electronic versions of the publication. SPIE uses a six-digit CID article numbering system in which:

- The first four digits correspond to the SPIE volume number.

- The last two digits indicate publication order within the volume using a Base 36 numbering system employing both numerals and letters. These two-number sets start with 00, 01, 02, 03, 04, $05,06,07,08,09,0 A, 0 B \ldots 0 Z$, followed by 10-1Z, 20-2Z, etc.

The CID number appears on each page of the manuscript. The complete citation is used on the first page, and an abbreviated version on subsequent pages. Numbers in the index correspond to the last two digits of the six-digit CID number. 


\section{Contents}

vii Conference Committee

xi Introduction

xiii Joint research for tomorrow's security and defence (Plenary Paper) [7483-31]

R. Krug, The Federal Ministry of Defence (Germany)

\section{FORCE PROTECTION AND SECURITY SESSION}

748004 Joint force protection advanced security system (JFPASS) "the future of force protection: integrate and automate" [7480-03]

C. E. Lama, Naval Surface Warfare Ctr. (United States); J. E. Fagan, U.S. European

Command (United States)

748005 Miniature dissolved oxygen and turbulence optical sensor for river and coastal environmental applications [7480-04]

E. M. Carapezza, Univ. of Connecticut (United States); G. Lombardi, J. Butman, Phase

Coherence (United States); I. Babb, Univ. of Connecticut (United States)

748006 A building block approach to security at shipping ports [7480-05]

R. C. Huck, M. K. Al-Akkoumi, S. Shammaa, J. J. Sluss, Jr., S. Radhakrishnan, T. L. Landers, Univ. of Oklahoma (United States)

748007 Configuration of a sparse network of LIDAR sensors to identify security-relevant behavior of people [7480-06]

K. Wenzl, H. Ruser, C. Kargel, Bundeswehr Univ. Munich (Germany)

748008 Remote control of open groups of remote sensors [7480-42]

P. Sapaty, Institute of Mathematical Machines and Systems (Ukraine)

\section{UNMANNED SYSTEM TECHNOLOGIES I}

7480 OD A new approach for determining reliability of unmanned vehicles network using fuzzy logic [7480-11]

A. Mustapha, H. Singh, K. Saab, Wayne State Univ. (United States); S. Rai, Louisiana State Univ. (United States); G. R. Gerhart, U.S. Army Tank-Automotive Research, Development and Engineering Ctr. (United States)

\section{UNMANNED SYSTEM TECHNOLOGIES II}

$7480 \mathrm{OF}$ Simulation of an algorithm for determining the reliability of unmanned ground vehicle networks [7480-14]

H. Singh, A. M. Dixit, K. Saab, Wayne State Univ. (United States); G. R. Gerhart, U.S. Army Tank-Automotive Research, Development and Engineering Ctr. (United States) 
$7480 \mathrm{OH}$ Collaborating miniature drones for surveillance and reconnaissance [7480-16]

A. Bürkle, Fraunhofer Institute for Information and Data Processing IITB (Germany)

ADVANCED FREE SPACE OPTICAL COMMUNICATIONS, TECHNIQUES AND APPLICATIONS

7480 ol Mobile optical high-speed data links with small terminals (Invited Paper) [7480-17]

D. Giggenbach, German Aerospace Ctr. (Germany)

7480 0J Cockpit to helmet optical wireless link: prototype hardware demonstration [7480-19] M. A. Watson, H. J. White, N. B. Aldridge, BAE Systems Advanced Technology Ctr. (United Kingdom); J. Lam, Ministry of Defence (United Kingdom); R. Atkinson, Optical Antenna Solutions Ltd. (United Kingdom)

7480 OK Ultra high efficiency 1550nm multi-junction pulsed laser diodes [7480-21] J-F. Boucher, Laser Components Canada, Inc. (Canada); V. Vilokkinen, Modulight, Inc. (Finland); P. Rainbow, Laser Components Canada, Inc. (Canada); P. Uusimaa, Modulight, Inc. (Finland); J. Lyytikäinen, S. Ranta, Tampere Univ. of Technology (Finland)

$7480 \mathrm{OL} \quad$ Retro-reflective communications over a kilometre range using a MEMS-based optical tag [7480-22]

A. M. Scott, K. D. Ridley, D. C. Jones, M. E. McNie, G. W. Smith, K. M. Brunson, A. Lewin, K. L. Lewis, QinetiQ Ltd. (United Kingdom)

\section{SENSOR NETWORKS}

$7480 \mathrm{ON}$ Integration of self-organizing map (SOM) and kernel density estimation (KDE) for network intrusion detection [7480-24]

Y. Cao, H. He, H. Man, Stevens Institute of Technology (United States); X. Shen, Ohio Univ. (United States)

7480 OP Gestalt-based integrity of distributed networked systems [7480-26]

P. Sapaty, Institute of Mathematical Machines and Systems (Ukraine)

\section{TARGET DETECTION AND TRACKING}

7480 OR Automatic detection of hostile behaviour [7480-28]

B. van den Broek, G. Burghouts, S. van den Broek, A. Smith, R. Hagen, L. Anitori,

W. van Rossum, TNO Defence, Security and Safety (Netherlands)

7480 OS Multiple human detection and tracking by using multiple-stage HOG detector and PFGPDM [7480-29]

Y. Yin, H. Man, Stevens Institute of Technology (United States); S. Desai, U.S. Army Research, Development and Engineering Command (United States); H. He, Stevens Institute of Technology (United States)

7480 ОT Using a multiple analytical distribution filter for underwater localization [7480-30]

D. Kruger, H. Shi, Y. Chen, H. Liu, J. Yang, L. Imas, Stevens Institute of Technology (United States) 
7480 OU Algorithms exploiting ultrasonic sensors for subject classification [7480-31]

S. Desai, S. Quoraishee, U.S. Army Research, Development and Engineering Command

(United States)

\section{NOVEL TECHNOLOGIES}

$7480 \mathrm{OW}$ On the recognition of compromise in sensing systems: rewired acoustic arrays and distorted route estimation and classification [7480-33]

D. J. Thornley, Imperial College London (United Kingdom); T. Damarla, Army Research Lab. (United States); M. B. Srivastava, Univ. of California, Los Angeles (United States);

D. Mylaraswami, Honeywell (United States)

\section{ACTIVE AND PASSIVE IMAGERS, IMAGE SENSING AND PROCESSING}

7480 OY Laser fabrication of silicon carbide detector for gas sensing and focal plane array imaging [7480-36]

G. Lim, The College of Optics and Photonics, Univ. of Central Florida (United States);

T. Manzur, Undersea Warfare Electromagnetic Systems Development (United States); A. Kar, The College of Optics and Photonics, Univ. of Central Florida (United States)

$7480 \mathrm{OZ}$ Improved object geo-location in airborne camera images using tight integration of vision and navigation data [7480-37]

C. Kessler, N. Frietsch, C. Schlaile, G. F. Trommer, Univ. of Karlsruhe (Germany)

748010 Image-based augmentation of an autonomous VTOL-MAV [7480-38]

N. Frietsch, A. Maier, C. Kessler, O. Meister, J. Seibold, G. F. Trommer, Univ. of Karlsruhe (Germany)

$748011 \quad$ Escherichia coli counting using lens-free imaging for sepsis diagnosis [7480-43]

S. Moon, F. Manzur, Brigham and Women's Hospital, Harvard Medical School (United States); T. Manzur, Naval Undersea Warfare Ctr. (United States); C. Klapperich, Boston Univ. (United States); U. Demirci, Brigham and Women's Hospital, Harvard Medical School (United States) and Harvard-Massachusetts Institutes of Technology Health Sciences and Technology (United States)

748012 GaN-based THz advanced quantum cascade lasers for manned and unmanned systems [7480-44]

A. F. M. Anwar, T. Manzur, Naval Undersea Warfare Ctr. (United States); K. R. Lefebvre, Sensis Corp. (United States); E. M. Carapezza, DARPA (United States)

Author Index 
Downloaded From: https://www.spiedigitallibrary.org/conference-proceedings-of-spie on 26 Apr 2023

Terms of Use: https://www.spiedigitallibrary.org/terms-of-use 


\title{
Conference Committee
}

\author{
Symposium Chairs
}

David H. Titterton, Defence Science and Technology Laboratory (United Kingdom)

Reinhard R. Ebert, Forschungsgesellschaft für Angewandte Naturwissenschaften e.V. (Germany)

Conference Chair

Edward M. Carapezza, DARPA (United States) and University of Connecticut (United States)

Program Committee

James S. Albus, National Institute of Standards and Technology (United States)

Mehdi Anwar, University of Connecticut (United States)

Sachi Desai, U.S. Army Research, Development and Engineering Command-ARDEC (United States)

Grant R. Gerhart, U.S. Army Tank-Automotive Research, Development and Engineering Center (United States)

Todd M. Hintz, Space \& Naval Warfare Systems Command SPAWARSYSCEN (United States)

Myron E. Hohil, U.S. Army Research, Development and Engineering Command (United States)

Ivan Kadar, Interlink Systems Sciences, Inc. (United States)

Leslie C. Laycock, BAE Systems (United Kingdom)

Nino Srour, Army Research Laboratory (United States)

Huub A. J. M. van Hoof, TNO Defense, Security and Safety (Netherlands)

\section{Session Chairs}

K1 Keynote Session 1

Edward M. Carapezza, DARPA (United States) and University of Connecticut (United States)

1 Force Protection and Security

Todd M. Hintz, Space \& Naval Warfare Systems Command SPAWARSYSCEN (United States)

Myron E. Hohil, U.S. Army Research, Development and Engineering Command (United States) 
K2 Keynote Session II

Edward M. Carapezza, DARPA (United States) and University of

Connecticut (United States)

Grant R. Gerhart, U.S. Army Tank-Automotive Research, Development and Engineering Center (United States)

2 Unmanned System Technologies I

Grant R. Gerhart, U.S. Army Tank-Automotive Research, Development and Engineering Center (United States)

Todd M. Hintz, Space \& Naval Warfare Systems Command SPAWARSYSCEN (United States)

3 Unmanned System Technologies II

Grant R. Gerhart, U.S. Army Tank-Automotive Research, Development and Engineering Center (United States)

Todd M. Hintz, Space \& Naval Warfare Systems Command SPAWARSYSCEN (United States)

$4 \quad$ Advanced Free Space Optical Communications, Techniques and Applications

Leslie C. Laycock, BAE Systems (United Kingdom)

K3 Keynote Session III

Edward M. Carapezza, DARPA (United States) and University of Connecticut (United States)

Todd M. Hintz, Space \& Naval Warfare Systems Command SPAWARSYSCEN (United States)

5 Sensor Networks

Myron E. Hohil, U.S. Army Research, Development and Engineering Command (United States)

Todd M. Hintz, Space \& Naval Warfare Systems Command SPAWARSYSCEN (United States)

$6 \quad$ Target Detection and Tracking

Myron E. Hohil, U.S. Army Research, Development and Engineering Command (United States)

Sachi V. Desai, U.S. Army Research, Development and Engineering Command (United States) 
$7 \quad$ Novel Technologies

Myron E. Hohil, U.S. Army Research, Development and Engineering Command (United States)

Sachi V. Desai, U.S. Army Research, Development and Engineering Command (United States)

$8 \quad$ Active and Passive Imagers, Image Sensing and Processing

Mehdi Anwar, University of Connecticut (United States)

Tariq Manzur, Naval Undersea Warfare Center (United States) 
Downloaded From: https://www.spiedigitallibrary.org/conference-proceedings-of-spie on 26 Apr 2023

Terms of Use: https://www.spiedigitallibrary.org/terms-of-use 


\section{Introduction}

The interest in unmanned/unattended sensors and sensor networks has dramatically increased over the past years. Corporations and government agencies are making large investments to develop related systems for military, homeland defense and security applications. Defending national assets and monitoring national coastlines and land borders are extremely challenging tasks. In large part, as a result of the commitment by conference presenters and attendees, significant progress has been made to develop significantly improved unmanned and unattended sensor technologies and systems.

The conference included four keynote talks and twenty seven presentations organized into eight sessions covering recent advances in force protection and security, unmanned system technologies, advanced free space optical communications, techniques and applications, sensor networks, target detection and tracking, novel technologies, active and passive imagers, and image sensing and processing.

Thanks to those who prepared and presented the technical papers and for their contribution to a very successful meeting. The success of this conference is attributed to the participation of the commercial, university, and government research-and-development community as well as the organizing efforts of the diverse and talented program committee. Thanks to our presenters and colleagues who traveled great distances to contribute to the success of this conference. Special thanks to our four keynote speakers: Dr. Cary Chabalowski (Office of Secretary of Army); Dr. John Dolan, (Carnegie Mellon University), Dr. Mark Campbell (Cornell University), and Dr. Pierre J. Corriveau (Naval Undersea Warfare Center). Additionally, special thanks to Robert T. Hintz from the Naval Air Warfare Center for a stimulating invited talk on the state-of-art of autonomous collision avoidance systems (ACAS) for unmanned air systems.

Special thanks to all of the session chairs who worked to help organize our program and who participated in this year's conference in Berlin, Germany including: Sachi Desai, U.S. Army Research, Development and Engineering Command; Grant R. Gerhart, U.S. Army Tank-Automotive Research, Development and Engineering Center Todd M. Hintz, Space \& Naval Warfare Systems Command SPAWARSYSCEN; Myron E. Hohil, U.S. Army Research, Development and Engineering Command; Leslie C. Laycock, BAE Systems (United Kingdom); and Tariq Manzur, Naval Undersea Warfare Center.

The conference was well attended this year, with a lot of interest in all the sessions. We hope the interest in this technology will continue to grow, and that this conference will expand with even greater technical content and significance in future years.

Edward M. Carapezza 
Downloaded From: https://www.spiedigitallibrary.org/conference-proceedings-of-spie on 26 Apr 2023

Terms of Use: https://www.spiedigitallibrary.org/terms-of-use 